ソ連では,小形モジュラ一炬 VTR-250 およびVTR -265 (電気出力 $100 \mathrm{MW}$ ), 原型炬 $\mathrm{VG}-400$ (電気出力 $265 \mathrm{MW}$ )の設計および技術開発が進められている。

中国では，重質油の㪕質油化扔上び回収の熱源とし て，ペブルベッド然料のヒジュール型炉を検討してい る.

\section{〔佐野川好母. 日本原子加研究所〕}

$11 \cdot 2 \cdot 4$ 国内外の安全研究 軽水炉反応度事故時 の燃料挙動に関する研究では，日本原子力研究所の NSRR 炉において，従来行ってきた未照射燃料による 実験に加えてバーンアップ燃料を用いた実験を行うた めの準備が進められている。

冷却材言失事故時の熱水力挙動に関する研究では, 在来形 BWRに関する研究計画の大半は終結したが, PWR に関しては日本原子力研究所の ROSA-IV 計画 をはじめとして大形装置による実験的研究が活発に進 められている，また，原子炉安全評価のための解析モ デルの合理化に関する作業も進捗した.

構造安全性の分野では，配管破壞挙動に関する近年 の研究成果をふまえ，アメリカでは従来の瞬時破断想 定学除外した新しい構造設計基準が導入された。

軽水炉のシビア・アクシデントについては，アメリ 力原子力規制委員会がアメリカの代表的な炉に関する リスク評価報告書（ドラフト）を公開し，その中でシ ビア・アクシデントのリスク評価に関して残された課 題を概括した。燃料破損挙動に関しては, LOFT 炉(ア メリカ）による実験で使用された燃料の実験後検査が 進み，またPHEBUS 炉(フランス)による寒験が開始 された.シビア・アクシデントを含む事故時の格納容 器挙動に関する実験的研究が日本原子力研究所抽よび 原子力工学試験センターで計画されている.

核燃料施設に関する安全研究の分野では，臨界安全 性に関する国際会議が我が国で開かれた，日本原子力 研究所では, 再処理施設の臨界安全性研究などのため 大規模な燃料サイクル安全工学研究施設 (NUCEF) の 建設を進めている。また，高レベル廃媟物ガラス固化 体の浸出試験が開始された。

原子力工学試験センターにおいては, 前年度に引続 き原子炉圧力容器の耐震信頼性実証試験, 燃料集合体 最大熱負荷試験, 原子炉圧力容器加圧熱衝擊試験など が行われた。

原子炉の確率論的リスク評価に関する研究が一層さ かんとなり，手法の開発とデータベースの整備が進ん だ。また人的要因関する研究，知識工学的手法によ る異常診断システムの開発などが活発化した。在来形 の軽水炉を対象とする安全性研究が高度化する一方,
受動的穻全性它取り入れた新しい軽水炉概念の提案も 活発に行初れた。

\section{[久林田 豊 日本原子力研究所]}

$11 \cdot 2 \cdot 5$ 核燃料サイクル 核燃料サイクルの確立 は，これが原子力の準国産エネルギーとしての位置付 けを確功ものにすることから，動力炉核燃料開発事 業団を中心とする研究機関等に抢ける技術開発や，民 間に対する事業化のためのさまざまな補助により政府 としてこれを積極的に推進しているところである，以 下に, 核燃料サイクルの主要工程である (a) ウラン濃縮 抢よび，(b) 使用済燃料再処理について，世界の現状と 今後の技術の動向について簡単に述べる.

a 、ウラン濃縮 現在, 世界の濃縮役務の大半は アメリカ, フランス, ソ連などが保有するガス搪散法 で供給されているが，本方式消費電力と冷却水の問 題から経済性に優る遠心分離法に取って代わられよう としている。遠心分離法は，ウレンコ(イギリス・オ ランダ・西ドイツ共同体）で実用化され，我が国でも 動燃事業団の試験プラントでの研究をもとに, 青森県 六ヶ所村の日本原燃産業(株)工場（66 年運開予定）で の採用が決まっている。 また，次世代の濃縮技術とし て注目されているものにウラン 235 の同位体シフトを 利用するレーザ法ウラン濃縮の技術がある。本方式は 慣性の差を用いる前二者と異なり，直接同位体を励起 して電極に回収するため効率が非常に高い. 我が国で も, 民間の研究組合や理化学研究所などで盛んに研究 開発が行われている.

b. 使用済燃料再処理 現在, 使用済燃料を商業 用に再処理している国は限られておりイギリス，フラ ンス，西ドイツなどがある。我が国は使用済燃料の一 部を動燃事業団の東海施設で再処理しているが, 大半 はイギリス,フランスでの海外再処理に依存している。 現在の再処理技術の主流は熱濃硝酸にせん断した燃料 を溶かし, 硝酸溶液と有機溶媒を接触させて U-Pu を 有機相に回収するピューレックス法である。青森県六 ヶ所村に日本原燃サービス(株)がフランスからの導入 技術を基に建設を進めている再処理工場（70 年頃運 開) でも，ピューレックス法の採用が決定していると ころである。

\section{〔大宮 正，通商産業省〕}

$11 \cdot 2 \cdot 6$ 核融合 トカマクでは, 日本原子力研究 所の JT-60 が，原子力委員会の定めた JT-60の目標 領域 (中心イオン温度: 数 $\mathrm{keV}$, 密度と閉込め時間の 積：(2-6) $\times 10^{19} \mathrm{~m}^{-3}$. $\left.\mathrm{s}\right)$ に到達した. EC の JET で は，プラズマ電流 $6 \mathrm{MA}$ の放電を生成した。また，ア メリカの TFTR では，1990 年に DT 燃㜔実験を目指 